\title{
Culture, Values and Integrity in Contemporary Society
}

\author{
Michael Willoughby Small
}

\begin{abstract}
Comments in the Australian press and the media have suggested that all is not well within certain sections of Australian society This view was publicised by comments of the Chief of the Australian Army, who had stated in vigorous terms that he intends to change the culture in the Army. Changing the culture of any organisation is difficult, slow and time consuming, and so in an endeavour to facilitate this process, it is argued that some thought might be given to studying some of the classical writers who were faced with similar problems thus illustrating the relevance and timeliness of their ideas.
\end{abstract}

In June 2013, the Chief of the Australian Army, stated in the strongest possible terms, in a telecast and then subsequently reported in The Australian Financial Review (Morrison, 2013) that the moral behaviour and the culture within sections of the Army were unacceptable. The purpose of this paper, therefore, is to look at terms such as morality, moral courage (as opposed to physical courage), integrity and duty which had been developed in earlier times, and see if these thoughts and ideas (which some claim are still relevant and timeless in this day and age) are applicable to the culture and behaviour of a modern Australia. The reason for addressing this topic is partly in response to media reports about moral behaviour in the Army, but mainly, it is in response to the comments that the Chief of Army made in relation to his troops having 'the integrity and the moral courage' to challenge questionable behaviour and culture within the Army.

Morality is a term which refers to the quality of being moral. It is used to define those practices and activities that are considered right and wrong; and can be related to conduct and character considered good or evil. Morality applies to the rules that govern those activities; and the values that are embedded and fostered by those activities and practices. Morality is also concerned with our judgements of what is right and wrong and what is good and bad. Moral judgements in respect to the rightness or wrongness of an action are held to be universally applicable and important, and moral blame can accompany acting immorally (De George, 2006, p. 37). Moral courage, as opposed to physical courage, is different. The term can be used in relation to people who have the fortitude or the resilience to face disapprobation or simply disapproval, ridicule, derision and mockery, particularly from members of their own community. Moral courage is one of the terms that the Chief of Army had in mind when he made his telecast about inappropriate behaviour within certain sections of the present day Army.

Many practices are taking place within the broader Australian society, practices which can only be described as questionable if not immoral. We see politicians from all sides of the political fence, officials both high and low, and people with access to expense accounts making claims on the public

Copyright (C) 2014 Victo ria University. This document has been published as part of the Journal of Business Systems, Governance and Ethics in both online and print formats. Educational and non-profit institutions are granted a nonexclusive licence to utilise this document in whole or in part for personal or classroom use without fee, provided that correct attribution and citation are made and this copyright statement is reproduced. Any other usage is prohibited without the express permission of the publisher. purse. We see footballers taking prohibited substances to give themselves an advantage and those most responsible taking every possible legal avenue in their attempts to escape responsibility; we see investors with inside knowledge trading on the stock market and business persons engaging in fraud and corruption. It seems this litany of indiscretions, even corrupt and immoral 
behaviour, is simply endless and unstoppable despite the efforts of those advocating an ethical approach in their business dealings. Business ethics today is possibly a lost cause. Consider the number of business schools which quote the starting salaries of graduates as evidence of their effectiveness when producing MBA's. No longer does ethics rule the world of business, if it ever did, but today the 'dollar' rules. In addition to the examples mentioned above, there is a minority within the Army who have been behaving in inappropriate and unacceptable ways.

Issues that involve morality, moral courage, integrity, duty and conduct relating to making the right decisions have been around for a long time. Cicero wrote some fatherly advice to his twenty-one year old son, Marcus, who had been in command of a cavalry squadron under Pompey, and who was supposed to be studying at a university in Athens-only he wasn't. The advice was eventually published as De Officiis i.e. On Duties (Cicero, trans. Walter Miller, 2005). This was Cicero's last work on moral philosophy completed in November $44 \mathrm{BC}$. That these qualities are still making news today suggests that ideas developed, discussed and written about two or three thousand years ago remain relevant. Cicero, the lawyer and politician, concerned himself with and wrote about topics such as wisdom, moral virtue, moral duty, moral propriety and moral rectitude. Julius Caesar and Thucydides also come to mind. Caesar was a highly successful soldier/general, writer of military despatches (but not much of a politician) and then dictator; and Thucydides, author of The Peloponnesian War, wrote about the war between Athens, the democratic sea power, and Sparta, the land based military super power.

The Chief of Army had stated in very strong language that the moral behaviour and culture in sections of the Army were unacceptable. He was reported as saying that if his troops did not respect the cultural values and the ethical standards that were expected of them, they should find other employment. He stated 'if that does not suit you, then get out, the standard you walk past is the standard you accept'. He continued saying that the troops were the custodians of the culture of their organisation, and if they encountered unacceptable and outrageous behaviour they should show moral courage and take a stand against it. The Chief of Army expected his troops to do the right thing, because it was the right thing to do, and if they were not up to it, then those persons should do something else with their lives. This was forceful language indeed about integrity, culture, values and ethical standards in the present day Australian army.

Two earlier case studies (Small and Minkes 2010) involved members of the Australian Defence Force (ADF); one involving HMAS Stirling Fleet Base West, submarine base and shore establishment of the Royal Australian Navy RAN; and the other examining the values, culture and training methods of the Special Air Service (SAS), Swanbourne, Western Australia.

In the first case study, the Navy's approach to ethical and moral behaviour in a military environment was examined. The situation that had brought about this study was not the same as the current situation within the Army. One reason for this study arose from a number of fatalities and the subsequent media publicity which had given an unfortunate impression of the RAN. The time therefore seemed appropriate to initiate a study into human resource policies and practices in the RAN.

Senior officers had described, in a series of personal discussions and interviews over a period of several weeks, a culture of 'social responsibility' and a sense of 'social awareness' that were evident among all personnel. This was extended to the ecology and the natural environment in which the base was situated. It was emphasised that both the Department of Defence and the Navy had an ongoing interest in the on-going pursuit of ethics and justice in a military environment. To illustrate, a professional reference library had been established with titles such as: 'Military Ethics and Professionalism: A Collection of Essays'; 'True Faith and Allegiance: The Burden of Military Ethics'; and 'Ethics and the Military Community'. In addition, Defence publications were available on a range of ethical issues e.g. 'Personal Rights'; 'Why all the Fuss about Ethics?'; 'The Whistle Blower-the Ethical Dilemma'; 'Codes of Conduct'; 'What has Ethics got to do with Defence?' and so on. Other journal articles covered subjects such as an explanation of 'natural law'; a discussion of Pope Paul VI's 
encyclical Humanae Vitae; and a collection of works in the fields of justice and ethics by well known writers in the area. Defence, as the co-ordinating government department overseeing the nation's defence assets, has coined the mnemonic implicit. This becomes meaningful if written as imPLICIT (i.e. professionalism, loyalty, innovation, courage, integrity and team work).

To emphasise this point, the Chief of Navy had stated in his mission statement (Australian Department of Defence, 2002):

Our values guide us how we will behave, how we will treat each other, what is important and what bonds us together. Values are our source of strength; they are the source of moral courage to take action.

The Navy while recognising the values that Defence had developed and promoted, had devised a set of its own based on the letters HHCIL (honour, honesty, courage, integrity and loyalty). When discussing these values, senior officers stated that HMAS Stirling wanted a value of its own so it made one up viz. esprit de corps. While not strictly a value, it did seem to be appropriate for the submarine service. In addition, the Navy uses the divisional system in caring for its personnel, a system which has been in place for many years in Royal Navies and has been likened to the 'house or form master' system. The Navy's position as outlined by the Commanding Officer, HMAS Stirling, in informal discussions, was that 'each member of the divisional chain of command is required to maintain a values-based approach to both professional and personal behaviour and ethics'. In earlier days when warships had large crews, the ships' complements were divided into divisions e.g. seaman, engine-room artificers and young sailors. Each division was the responsibility of a divisional officer who was available for advice or counselling. Sometimes chaplains undertook this role.

In the other case study the values, culture and training methods of the SAS based at Swanbourne, Western Australia were studied. While the mnemonic imPLICIT referred to above was acknowledged, the unit spokesman insisted on pointing out that the SAS had a set of values of its own viz. the relentless pursuit of excellence, a classless sense of family, discipline, primacy of operational capability, humility, a sense of humour, loyalty and respect for absent mates. The spokesman stressed that these values were vigorously encouraged and pursued. In terms of organisational culture, knowledge of and familiarisation with the unit's culture were embedded in new members during the crucial initial training period. Living strictly according to the unit's code of ethics, and demonstrating judgement and humility were looked for in an individual seeking admission to this unit. Potential members were often required to operate in culturally diverse environments, and so the characteristics referred to above were thought to be very important. In terms of practical relevance, the unit demonstrates its capability as a highly trained and specialised army unit when engaging in its primary role on operations.

\section{Relevance of Earlier Thinking on Key Concepts to Current Issues}

Comments about issues such as those reported above, such as integrity, moral behaviour and moral courage have their base in ideas and writings originating in Greco-Roman times. It could be argued, therefore, that some familiarity with themes from these early sources could be justified when planning courses to address moral issues for soldiers in the present-day Army. Nobody could expect young soldiers to spend their time reading the works of Cicero or Plato, but as their writings have influenced our thinking on moral issues today we might reasonably expect that members of the ADF would be presented with a selection of the thoughts and ideas of these early figures whether in the initial training periods at officer-cadet level or in basic recruit training.

Plato, Aristotle and Cicero are probably the most well known of the early philosophers, but there were others e.g. Panaetius, Hecaton, Seneca and Plutarch, who had made significant contributions to developing a body of knowledge relating to integrity, duty and moral issues. Their ideas could be incorporated into a program on leadership and moral behaviour similar to programs run in UK, US and Canadian military training establishments. They could also add to the already existing programs in leadership programs. 


\section{The Concept of Duty Then and Now}

Duty is defined here as that which is due, or what one is bound to do by any moral obligation. Duty as an idea or concept featured heavily in ancient Greece, and appears in the works of early Greek writers, one of whom was Panaetius. He was a Stoic philosopher from the island of Rhodes, and the author of a three volume text entitled 'On the theory of Moral Obligation', in other words, doing one's duty, a work upon which Cicero based his De Officiis, (Smith and Marindin 1989, p.426). This title itself, 'On Duties', could be the basis of a course on the 'Meaning of Duty' dating from earliest times in Western Europe. Prime Minister Abbott (2013) referred to duty when addressing Australian troops in Tarin Kot, Afghanistan. The PM spoke about the 'bittersweet' ending of the war and added: 'Our armed forces and our officials have done their duty. That duty never ends, although our duty here has'. This item was flagged by the headline 'Duty of War'. So 'Duty' and 'doing the right thing' are significant, not only in ancient times, but also to-day.

Cicero (Cicero, trans. Walter Miller, 2005) the lawyer and politician, took a legalistic and philosophical approach. He wrote that we should distinguish between two types of duty (mean i.e. ordinary duty and absolute i.e. what is right). He referred to Panaetius who would ask (himself) questions such as: 'Is a contemplated act morally right or wrong?' 'Is it advantageous or disadvantageous?' 'If apparent right and apparent advantage clash, what is to be the basis for our choice between them?'

Caesar was the soldier/general who spoke and wrote about values such as 'honour, duty and cowardice' (Caesar, trans. H.J.Edwardes, 1986) Hecaton, a student of Panaetius, also produced a text 'On Duties' written for the consul Quintus Tubero. Panaetius and Hecaton influenced the writings of Cicero and Seneca. Their works, produced much later, contain references to Panaetius and Hecaton. Cicero's (Cicero, trans, Miller, 2005) views on moral duty, in $44 \mathrm{BC}$, are still relevant in the $21^{\text {st }}$ century. Here Cicero is repeating, in part, what Hecaton of Rhodes (Cicero, trans. Walter Miller, page 333 or Book III, 63, 2005) had said about moral duty. This whole section is highly relevant and commences as follows:

it is a wise man's duty to take care of his private interests, at the same time doing nothing contrary to the civil customs, laws, and institutions.

Cicero (ibid) completed 'On Duty' in November 44 BC. It contained advice outlining principles of moral duty and practical rules for personal conduct. As noted above, it was written especially for his son, Marcus, who was supposed to be studying in Athens. Cicero focused on the four cardinal virtues i.e. wisdom, justice, fortitude and temperance and the duties that stemmed from these virtues. $\mathrm{He}$ spelt out how he expected 'a wise man' to behave in public and in private. For example, it could be argued that everybody has a duty to take care of his/her private interests, but as Cicero pointed out ('at the same time do nothing contrary to the civil customs, laws, and institutions' (Cicero, trans. Walter Miller, page 333 or Book III, 63, 2005). The key section is 'do nothing contrary to the civil customs, laws, and institutions'.

Some behaviour, both in the wider community and in the Army, is 'contrary to the civil customs, laws, and institutions', and therefore as the Chief of Army has argued such behaviour must be managed more effectively. As an example, there was the case, 23 October 2013, involving the behaviour of officer-cadets at the Defence Academy. The decision of the Court, was to award 'Good Behaviour Bonds' with the final decision (termination) being announced in the media, 8 November 2013. This was followed by another media release, 8 November 2013, of an incident on HMAS Ballarat, which suggested that a case could be justified in both instances (thus following Seneca's ideas of philosophic self-scrutiny focussed on knowing oneself) to discuss and reflect upon the meaning of duty.

Seneca was Nero's tutor and later his advisor. He had strong views on duty, which at that time was courageous. He lived in a volatile and tumultuous period and eventually incurring Nero's displeasure 
he was ordered to commit suicide. Seneca, following his teacher Sotion, is reputed to have favoured the practice of philosophic self-scrutiny. This was similar to an examination of conscience in Christian terms. It was originally a Pythagorean idea, and something to which both Cicero and Seneca subscribed. A person would ask himself the following questions every night before sleep (Seneca trans. Basore, p. 107 ff., 1928a):

What bad habit have you cured today? What moral fault have you resisted? In what respect are you better?

He wrote thirteen 'Treatises/Dialogues' and 124 letters on ethical issues (Seneca, trans. Basore 1928a). In one composition he played the part of the dutiful son advocating strong family values. In another, he mused about the mind and how to cope with the pressures of daily living. In a third, Seneca emphasised the value of time and the fact that life is short. In another essay, he wrote that: 'life's tribulations must be endured with fortitude'. In the dialogue about anger, Seneca described the difference between anger and irascibility, between being drunk and being a drunkard, and the difference between being frightened and being a coward. These comments and the lessons contained with them could be applied to some behaviour in today's society.

The Chief of Army has promised that there will be changes in the culture of the Army, but changing an organisation's culture is difficult, challenging and slow. It requires a different mindset to the one existing at the present time. In subsequent developments, the Army announced that it had identified six officers and NCOs who were identified as the leaders of the 'Jedi Council' pornography network (The Weekend Australian, 2013). Other personnel are also involved and twelve officers are facing dismissal or disciplinary action. The same item also included a report that a total of 2,400 complaints of sexual and other abuse had been received going back to the 1950s. Managing this type of behaviour in an organisation as complex as an army whose members are physically fit, intelligent and young will be a challenge for those responsible for the total well-being of the organisation.

What conclusions can be drawn from this brief look at of some of the issues and problems relating to 'moral courage, integrity and duty' within the present day Army and by implication the broader Australian society? The Chief of Army has stated that he wants to rectify a difficult situation in respect to the culture and personal behaviour as practised within the Army. The thoughts and writings of a few bygone philosophers are not going to bring about an immediate change in the culture of an organisation, but reflecting on and discussing ideas which were first articulated two thousand years ago may lead to an understanding of moral issues that have been talked about for more than two thousand years.

\section{Conclusion}

To conclude, the main points are that issues relating to concepts such as morality, moral courage, integrity and duty are important and should be taken seriously. If not dealt with in a timely and appropriate manner, unintended consequences may arise. Questions that Panaetius and Seneca asked: 'Is a contemplated act morally right or wrong? or 'What moral fault have you resisted?' and 'In what respect are you better?' are relevant and significant. They could become embedded in programs in business, management, medicine in addition to the armed forces. Understanding the meaning of 'duty and moral duty' is as relevant and important today as it was in ancient times, probably even more so. These areas should be included in leadership programs for students of all ages and in all areas of endeavour. 


\section{References}

Abbott, T. 2013, The Australian Financial Review, 30 October, p. 1.

Australian Department of Defence, 2002 Navy, Mission Statement 2001-2002. Canberra, Department of Defence.

Caesar, 1986, The Gallic War, with an English translation by H. J. Edwardes, The Loeb Classical Library, Cambridge, Mass: Harvard University Press.

Cicero, 2005, Cicero De Officiis, On Duty, XXI, with an English translation by Walter Miller, The Loeb Classical Library, Cambridge, Mass: Harvard University Press.

De George, R. T. 2006, Business Ethics, $6^{\text {th }}$ ed., Pearson Prentice Hall, New Jersey, pp. 19, 37.

Morrison, D. 2013, 'What I know now', The Australian Financial Review, Boss Magazine, November, Volume 14, p. 58.

Seneca, 1928a. Moral Essays with an English translation by John W. Basore, in Three Volumes, London: William Heinemann Ltd.

Seneca, Epistulae Morales I, 1928b. with an English translation by R. M. Gummere, London: William Heinemann Ltd.

Small, M.W. and L. Minkes, 2010, 'On the nature of learning communities: a study of four organisations', The Journal of Management Development, Volume 29, No. 9, pp. 783-794.

Smith, W. and Marindin, G.E 1898, A Smaller Classical Dictionary of Biography, Mythology, and Geography, $28^{\text {th }}$ Impression, John Murray, Albemarle Street, London, p. 426.

The Weekend Australian 2013, 'Jedi Council' pornography network, November 16-17, p. 3 